Chirurgia (2017) 112: 259-277

No. 3, May - June

Copyright $\odot$ Celsius

http://dx.doi.org/10.21614/chirurgia.112.3.259

\title{
Liver Resections in a High-Volume Center: Form Standard Procedures to Extreme Surgery and Ultrasound-guided Resections
}

\author{
Florin Botea', Mihnea Ionescu', Vladislav Brașoveanu', Doina Hrehoreț', Sorin Alexandrescu', Mihai Grigorie', \\ Oana Stanciulea', Diana Nicolaescu', Dana Tomescu' ${ }^{2}$, Gabriela Droc'2, Daniela Ungureanu'2, Ruxandra Fota'2, \\ Adina Croitoru ${ }^{3}$, Liana Gheorghe ${ }^{4}$, Cristian Gheorghe ${ }^{4}$, Ioana Lupescu ${ }^{5}$, Mugur Grasu ${ }^{5}$, Mirela Boroș ${ }^{5}$, Radu Dumitru ${ }^{5}$, \\ Mihai Toma ${ }^{5}$, Vlad Herlea ${ }^{6}$, Irinel Popescu'
}

${ }^{1}$ Center of General Surgery and Liver Transplantation, Fundeni Clinical Institute, Bucharest, Romania ${ }^{2}$ Center of Anesthesia and Intensive Care, Fundeni Clinical Institute, Bucharest, Romania ${ }^{3}$ Department of Medical Oncology, Fundeni Clinical Institute, Bucharest, Romania ${ }^{4}$ Center of Gastroenterology, Fundeni Clinical Institute, Bucharest, Romania ${ }^{5}$ Center of Diagnostic and Interventional Radiology, Fundeni Clinical Institute, Bucharest, Romania ${ }^{6}$ Department of Pathology, Fundeni Clinical Institute, Bucharest, Romania

Corresponding author: Irinel Popescu, MD, FACS, FEBS Professor of Surgery "Dan Setlacec" Center of General Surgery and Liver Transplantation Fundeni Clinical Institute Sos. Fundeni, 258, 022328, Bucharest, Romania E-mail: irinel.popescu@icfundeni.ro

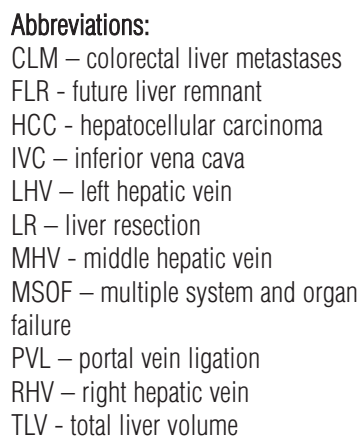

\section{Rezumat}

Rezecțiile hepatice într-un centru terțiar: de la proceduri standard la chirurgia extremă și rezecții ecoghidate

Introducere: Rezecția hepatică este tratamentul de elecție pentru majoritatea leziunilor focale hepatice benigne şi maligne, şi în cazuri selectionate de traumatisme hepatice. Putine alte metode terapeutice pot egala eficiența rezecției hepatice în cazuri selecționate, cum ar fi transplantul hepatic pentru carcinom hepatocelular şi terapiile de ablație tumorală pentru carcinomul hepatocelular sau metastaze de mici dimensiuni. Lucrarea de față analizează experiența centrului nostru în rezecții hepatice, analizând indicațiile, tehnicile chirurgicale si rezultatele postoperatorii imediate.

Material şi Metodă: În perioada Ianuarie 2000 - Decembrie 2016, în Centrul de Chirurgie Generală şi Transplant Hepatic "Dan Setlacec" s-au efectuat 3165 rezecții hepatice la 3016 pacienți; pacientii cu rezecții hepatice pentru donare de grefă în vederea trasplantului hepatic au fost excluşi din analiză. Vârsta mediană a fost de 56 ani (medie 58, interval 1-88), cu un raport bărbați/femei de 1524/1492 şi raport adulți/copii de 2973/43.

Rezultate: Indicația principală de rezecție hepatică au fos tumorile maligne (2372 cazuri; $74,9 \%$ ), din care cele mai frecvente au fost 
metastaze hepatice colorectale (952 cazuri; 30,1\%) şi carcinomul hepatocellular (575 cazuri, 18,2\%). Numărul maxim de tumori rezecate per pacient a fost de 21, iar diametrul median a celei mai mari tumori rezecate a fost de $40 \mathrm{~mm}$ (medie $51 \mathrm{~mm}$; range $3-250$ ). Rata de rezectii hepatice majore a fost de 18,6\% (588 cazuri); în 789 cazuri $(24,9 \%)$ s-au realizat rezecții hepatice anatomice. Timpul operator median a fost de 180 minute (media 204; interval 45-920). Pierderile sanguine intraoperatorii mediane au fost de $500 \mathrm{ml}$ (media 850; interval 500-9500), cu o rată de transfuzii de 41,6\% (1316 cazuri). Rata de morbiditate a fost de 40,1\% (1270 cazuri), iar cea de complicații majore (cel puțin clasa IIIa Dindo-Clavien) a fost de 13,2\% (418 cazuri). Rata de mortalitate a fost de 4,2\% (127 pts).

Concluzii: Pentru a obține rezultate optime, cu morbiditate şi mortalitate reduse, rezecțile hepatice trebuie realizate în centre supraspecializate.

Cuvinte cheie: rezecție hepatică, tehnici chirurgicale, leziuni hepatice focale, experiența single-center

\section{Abstract}

Background: Liver resection (LR) is the treatment of choice for most benign and malignant focal liver lesions, as well as in selected patients with liver trauma. Few other therapies can compete with LR in selected cases, such as liver transplantation in hepatocellular carcinoma (HCC) and ablative therapies in small HCCs or liver metastases. The present paper analyses a single center experience in LR, reviewing the indications of LR, the operative techniques and their short-term results.

Material and Method: Between January 2000 and December 2016, in "Dan Setlacec" Center of General Surgery and Liver Transplantation were performed 3165 LRs in 3016 patients, for pathologic conditions of the liver. In the present series, liver resections for living-donor liver transplantation were excluded. The median age of the patients was 56 years (mean 58 years; range 1-88), with male/female ratio 1524/1492 and adult/pediatric patient ratio 2973/43.

Results: Malignant lesions were the main indication for LR (2372 LRs; 74.9\%). Among these, colorectal liver metastases were the most frequent indication (952 LRs; 30.1\%), followed by hepatocellular carcinoma (575 patients, 18.2\%). The highest number of resected tumors per patient was 21 , and the median diameter of the largest tumor was $40 \mathrm{~mm}$ (mean $51 \mathrm{~mm}$; range 3-250). Major resections rate was $18.6 \%$ (588 LRs) and anatomical LRs were performed in 789 patients $(24.9 \%)$. The median operative time was 180 minutes (mean 204 minutes; range 45-920). The median blood loss was $500 \mathrm{ml}$ (mean $850 \mathrm{ml}$; range 500-9500), with a transfusion rate of 41.6\% (1316 LRs). The morbidity rate was $40.1 \%(1270 \mathrm{LRs})$ and the rate of major complications (Dindo-Clavien IIIa or more) was $13.2 \%$ (418 LRs). Mortality rate was $4.2 \%$ (127 pts).

Conclusion: LRs should be performed in specialized high-volume centers to achieve the best results (low morbidity and mortality rates).

Key words: liver resection, surgical techniques, focal liver lesions, single-center experience

\section{Background}

Liver resection (LR) has long been regarded as one of the most difficult and challenging procedure in general surgery, due to the historical increased rates of postoperative morbidity and mortality. Moreover, major hepatectomies (resection of 3 or more liver segments) were initially associated with morbidity and mortality rates exceeding $50 \%$ and $10 \%$, respectively (1). Because of the continuous advancements in preoperative imaging and intraoperative devices, as well as 
refinement in surgical techniques and intensive care procedures, the morbidity and mortality rates decreased over the last decades, while the indications of LR extended. Consequently, nowadays LR became a standardized procedure with morbidity rates up to $30 \%$, mortality rates less than $5 \%$ and blood transfusion rates lower than $50 \%(2,3,4)$. Although significant improvements have been achieved during the past decades, postoperative bleeding, bile leak, liver failure and sepsis related to the cut-surface abscess still remain the most common challenges for a successful LR. The present paper analyses a single center experience in LR over a 17 years period, focusing on the indications of LR, operative techniques and the short-term results that were achieved.

\section{Patients}

A total of 3016 patients underwent 3165 LRs in "Dan Setlacec" Center of General Surgery and Liver Transplantation, Fundeni Clinical Institute during the last 17 years (from January 2000 to December 2016). The median age of the patients was 56 years (mean 58 years, range 1-88) and the male/female ratio was 1524/1492. At the time of LR, 2973 patients $(98.6 \%)$ were at least 18 years-old, while 43 patients (1.4\%)ounger than 18 yearsold. In 12 patients, LR was performed after previous portal vein ligation (PVL). A twostage procedure was performed in $5 \mathrm{pts}(0.1 \%)$, 3 of them undergoing PVL during the first stage. In one patient the resectability was achieved by an ALPPS procedure (Associated Liver Partition and PVL for Staged hepatectomy). A subgroup of 132 patients (4.2\%) underwent repeat LRs: in 115 patients (3.6\%) was performed one re-resection, while 12 patients $(0.5 \%)$ received two re-resections.

The proportion of LRs (out of all operations performed in the center during the mentioned period of time) represented 5.4\% (3165 LRs out of 58948 operations). To assess the trend of LRs' proportion over the time, the entire period was divided in four intervals (Table 1). The number of LRs progressively increased during this period and also the proportion of LRs significantly
Table 1. Evolvement of LR (number and percentage) overtime

\begin{tabular}{lccc}
\hline Year & $\begin{array}{c}\text { All operations } \\
\text { (No of cases) }\end{array}$ & $\begin{array}{c}\text { Liver resections } \\
\text { (No of cases) }\end{array}$ & $\%$ \\
\hline $2000-2004$ & 16909 & 541 & 3.2 \\
\hline $2005-2008$ & 15449 & 821 & 5.3 \\
\hline $2009-2012$ & 13263 & 787 & 5.9 \\
\hline $2013-2016$ & 13327 & 1016 & 7.6 \\
\hline TOTAL & 58948 & 3165 & 5.4 \\
\hline
\end{tabular}

increased from the first to the last interval (3.2\% in the first interval vs. $7.6 \%$ in the last interval, $\mathrm{p}<0.01)($ Table 1).

\section{Methods}

We analyzed an HPB database with data collected prospectively (preoperative and intraoperative data) and retrospectively (postoperative data) from the medical records of patients undergoing LR in our center during the last 17 years. Patient demographics, indications for LR, intraoperative data (tumor location, type of LR, the use of vascular control methods, procedures associated with LR, the amount of blood loss, blood transfusion requirements, duration of surgery), pathologic report (number of lesions, largest tumor size and histological type) and postoperative data (type of postoperative complications and mortality within 90 days from surgery) were recorded and analyzed. Several surgical teams operated along the time, the two main teams being led by Professor Irinel Popescu and Associate Professor Mihnea Ionescu, respectively. In order to evaluate different changes in surgical treatment and outcomes along the time, the entire period was divided in 4 intervals, as it was presented above (Table 1).

\section{Study end-points}

The primary end-point was the short-term surgical outcome, consisting in morbidity and mortality rates. Morbidity is defined as any postoperative complication occurring in the first 90 postoperative days (POD) and mortality represents any death occurring during the first 90 POD. The postoperative complications were graded according to Dindo-Clavien classifica- 
tion; major morbidity included all complications classified between IIIA and V. The secondary end-point of the study was the evaluation of the types of LR used in the present series.

\section{Preoperative Evaluation}

The protocol of preoperative imaging included contrast-enhanced CT scan of the thorax, abdomen and pelvis and/or contrast-enhanced magnetic resonance imaging (MRI) in case of uncertain diagnosis or in patients who cannot tolerate CT scan. When distant metastases were suspected, bone scintigraphy and/or FDG-PET were considered.

Liver function tests, tumor markers (CEA, CA 19-9, AFP) and viral hepatitis tests were performed in all patients diagnosed with liver masses. Moreover, upper GI endoscopy and colonoscopy were also routinely performed.

In patients with normal liver parenchyma and good performance status, LR was recommended when preoperatively it was anticipated the ability to perform an $\mathrm{R} 0$ resection and the volume of future liver remnant (FLR) exceeded $25-30 \%$ of total liver volume (TLV). In patients with chemotherapy induced steatohepatitis or sinusoidal obstruction syndrome, as well as in patients with chronic hepatitis, LR was performed when FLR volume was higher than $40 \%$ of TLV. Child A cirrhotic patients, with platelets count of more than $100.000 / \mathrm{mm}^{3}$ and no ascites, were considered for LR if FLR volume exceeded $40-50 \%$ of TLV. When intraoperative evaluation revealed macro-nodular liver cirrhosis, $L R$ was precluded, usually being performed an ablative therapy (radiofrequency, microwaves, alcohol injection). In patients with multiple malignant liver tumors which cannot be entirely resected, to increase the possibility of complete clearance of the liver, LR was associated with different methods of tumor ablation.

For each patient with malignant liver tumors, the decision of LR was established by a multidisciplinary team, including surgeons, radiologists, oncologists, pathologists and gastroenterologists.

\section{Surgical Technique}

Most LRs were performed by open approach, while minimal invasive approach (laparoscopic or robotic) was used in selected cases. Anatomical LRs were classified according to the anatomical nomenclature of Brisbane 2000 terminology for liver anatomy and resections (5). Major LR was defined as the removal of at least three segments. All established surgical techniques were used: anatomical/non-anatomical hepatectomies, major/ minor resections, extra/ intra-glissonian approaches, LRs with/without prior liver mobilization, ultrasound-guided LRs, two-stage LRs, ALPPS approach and ex-situ LRs. Moreover, all established methods for parenchyma transection were deployed, according to the team preference and the status of liver parenchyma: clamp crushing method (Kellyclasia) (6), combined unipolar and bipolar cautery (for simultaneous hemostasis while transaction) (7), electrothermal bipolar vessel sealing (8), harmonic scalpel (9), radiofrequency /microwave device (including Habib 4x device) (10), cavitron ultrasonic surgical aspirator (CUSA) (11) and endo-GIA vascular staplers (12). The first 3 described methods were most frequently used in the present series, similar to many centers around the world (3) (4). Since none of these methods clearly proved its superiority (13), the parenchyma transection technique depends on the surgical team preference and the status of liver parenchyma. Vascular control, consisting in Pringle maneuver and total vascular exclusion, was also used according to team preference and hemodynamic tolerance, in order to reduce the blood loss during LR. The most common used methods to control bleeding on the cut-surface of the liver were ligatures, sutures, monopolar, bipolar and/or argon electrocoagulation, radiofrequency ablation, fibrin sealant patch, hemostatic powder and the newly implemented method using autologous fibrin sealant.

Technically demanding LRs (complex LRs) were defined based on the following criteria:

- Tumor characteristics: at least $10 \mathrm{~cm}$ diameter and/or more than 3 bilobar lesions; 
- Status of the liver parenchyma: cirrhosis;

- Type of LR: resection of the middle segments (segments 4, 5, 8), right posterior sectionectomy (segments 6, 7), right posterior sectionectomy extended to the right anterior section and/or segment 1 , isolated segmentectomy 1 , transverse hepatectomy (segments 4, 5, 6), nonanatomical extended hemihepatectomies, trisectionectomies, two-stage hepatectomies, ALPPS;

- Associated resections: portal/ hepatic artery/ inferior vena cava resection and reconstruction, biliary resection and reconstruction, other organ(s) resections;

\section{Short-term Outcome}

All postoperative complications that occurred in the first 90 POD were recorded and classified according to Dindo-Clavien classification (14). Complications leading to life-threatening conditions (grade IIIA and above) were considered as major morbidity; these included postoperative bleeding, abscess, sepsis, any organ failure. Complications with no fatal potential were considered minor, (Dindo-Clavien grade I-II). Liver-related complications were defined as all complications directly related to the LR, such as bile leak, cut-surface hematoma or abscess, hemoperitoneum, ascites, liver failure. The major complication rate was calculated based the most severe complication for each LR. Operative mortality was defined as death during surgical procedure or within 90 POD.

\section{Statistical Analysis}

Continuous parameters were expressed as median, mean and ranges. Categorical variables were expressed in absolute number and percentage. The Mann-Whitney test was useed to compare nonparametric data and the Chi-square test or Fisher's exact test were applied for analysis of categorical variables. The level of statistical significance was set at $p$ value $<0.05$.

\section{Results}

\section{Indications for $L R$}

The majority of resected lesions were malignant (2372 LRs; 74.9\%); among these, colorectal liver metastases (CLM) were the most frequent tumors (952 LRs; 30.1\%), followed by hepatocellular carcinoma (HCC) (575 tumors, 18.2\%). Benign tumors represented $24 \%$ of resected cases $(658 \mathrm{LRs})$, hemangioma being the most frequent (305 LRs; 9.6\%). 1.1\% LRs were performed for liver trauma (Table 2).

The incidence of LRs performed for malignant lesions increased overtime, from $67.7 \%$ (in 2000-2004) to $76.8 \%$ (in 2013-2016) ( $\mathrm{p}=0.03$ ). Contrarily, the incidence of non-malignant lesions decreased overtime: from $32.3 \%$ (in 2000-2004) to $23.2 \%$ (in 2013-2016) ( $\mathrm{p}=0.02)$ (Fig. 1). The incidence of LRs performed for colorectal liver metastases, non-colorectal liver metastases and intrahepatic cholangiocarcinoma significantly increased overtime: from $25.0 \%$ to $29.7 \%(\mathrm{p}=0.04)$, from $9.6 \%$ to $13.2 \%(\mathrm{p}=0.05)$ and from $1.3 \%$ to $2.9 \% \quad(p=0.01)$, respectively.

Table 2. Type of resected lesions (pathologic diagnosis)

\begin{tabular}{lcc}
\hline Tumor type & No of cases & $\%$ \\
\hline Malignant tumors & 2372 & 74.9 \\
\hline Colorectal liver metastases & 952 & 30.1 \\
\hline Hepatocellular carcinoma & 575 & 18.2 \\
\hline Non-colorectal liver metastases & 352 & 11.1 \\
\hline Other malignant tumors & 231 & 7.3 \\
\hline Klatskin tumor & 113 & 3.6 \\
\hline Gallbladder cancer & 73 & 2.3 \\
\hline Peripheral cholangiocarcinoma & 61 & 1.9 \\
\hline Hepatoblastoma & 15 & 0.5 \\
\hline Benign tumors & 658 & 24.0 \\
\hline Haemangioma & 305 & 9.6 \\
\hline Focal nodular hyperplasia & 91 & 3.3 \\
\hline Liver Abscess & 81 & 0.5 \\
\hline Adenoma & 73 & 2.9 \\
\hline Liver hydatid cyst & 70 & 2.3 \\
\hline Biliary cyst & 15 & 2.2 \\
\hline Caroli disease & 11 & 2.6 \\
\hline Localized liver necrosis & 6 & 0.3 \\
\hline Intrahepatic lithiasis & 3 & 0.2 \\
\hline Other benign tumors & 104 & 0.1 \\
\hline Liver trauma & 34 & 1.1 \\
\hline TOTAL & 3165 & 100 \\
\hline & & \\
\hline
\end{tabular}




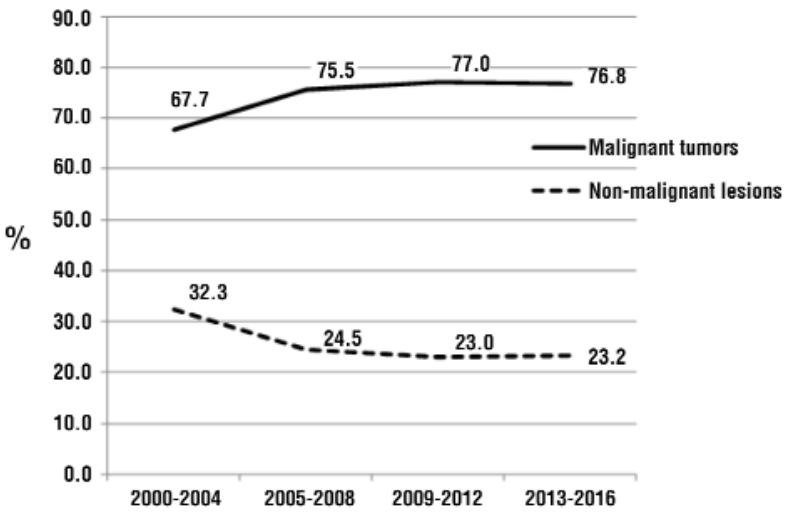

Figure 1. Trends of the incidence of malignant and benign lesions overtime

Conversely, hemangioma (as indication for LR) significantly decreased overtime, from $15.5 \%$ to $7.2 \%(\mathrm{p}=0.01)$. Incidence of HCC and Klatskin tumor among patients undergoing LR was relatively stable overtime: from $16.3 \%$ to $18.5 \%$ $(\mathrm{p}=0.5)$ and from $4.4 \%$ to $3.2 \%(\mathrm{p}=0.6)$, respectively (Fig. 2).

The median number of resected lesions was 1 (mean 1.5; range 1-21); $163 \mathrm{LRs}$ (5.1\%) were performed for more than 3 lesions. The median diameter of the main lesion was $40 \mathrm{~mm}$ (mean $51 \mathrm{~mm}$; range 3-250); $376 \mathrm{LRs}$ (11.9\%) were performed for lesions larger than $100 \mathrm{~mm}$. Lesions were most frequently located in the right hemiliver (1383 LRs; 43.7\%) (Table 3).

\section{LR Technique}

The open approach was used in 3050 LRs (96.4\%), while laparoscopic and robotic approach were performed in $77 \mathrm{LRs}(2.4 \%)$ and $38 \mathrm{LRs}(1.2 \%)$, respectively.

Major hepatectomy was performed in 588 patients (18.6\% of LRs). The rate of major LRs

Table 3. Topography of the focal liver lesions

\begin{tabular}{lcc}
\hline Lesion topography & No of LRs & $\%$ \\
\hline Right hemiliver & 1383 & 43.7 \\
\hline Left hemiliver & 1022 & 32.3 \\
\hline Bilobar & 726 & 22.9 \\
\hline Segment 1 (alone) & 34 & 1.1 \\
\hline TOTAL & 3165 & 100.0 \\
\hline
\end{tabular}

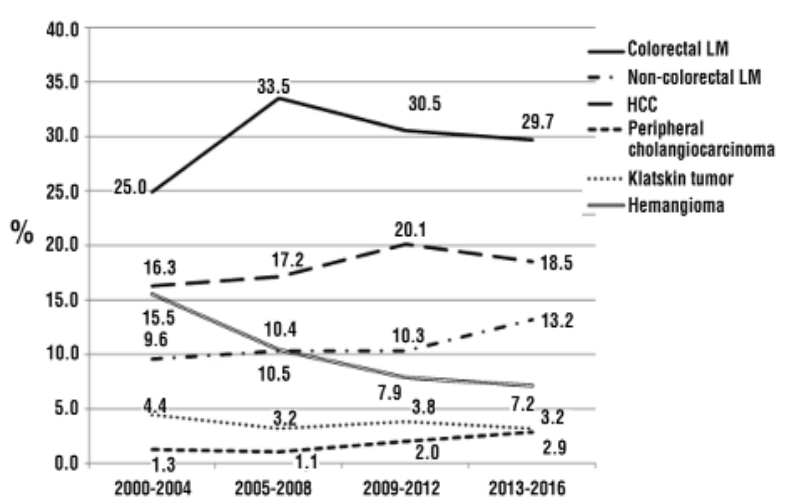

Figure 2. Trends of the incidence of main types of lesions overtime

significantly decreased overtime, from $23.8 \%$ (216 LRs) in $2000-2004$, to $16.98 \%$ (171 LRs) in $2013-2016(\mathrm{p}=0.04)$.

Anatomical resections were performed in 789 cases (24.9\%) (Table 4); out of these, 104 (3.3\%) had associated limited non-anatomical LRs.

According to the above-mentioned criteria, 1495 LRs $(47.2 \%)$ were technically complex hepatectomies (Table 5). The rate of these

Table 4. Type of liver resection (LR)

\begin{tabular}{lcc}
\hline Type of liver resection & No of pts & $\%$ \\
\hline Major resections & 588 & 18.6 \\
\hline Minor resections & 2577 & 81.4 \\
\hline Anatomical resections & 789 & 24.9 \\
\hline Trisectionectomy & 36 & 1.1 \\
\hline Right hemihepatectomy & 243 & 7.7 \\
\hline Left hemihepatectomy & 108 & 3.4 \\
\hline Central LR (anatomic) & 9 & 0.3 \\
\hline Transversal LR & & \\
(resection of segment IV, V and VI) & 3 & 0.1 \\
\hline Bisegmentectomy & 320 & 10.1 \\
\hline Posterior right sectionectomy & 37 & 1.2 \\
\hline Anterior right sectionectomy & 7 & 0.2 \\
\hline Isolated segmentectomy I & 26 & 0.8 \\
\hline Non-anatomical resections & 2376 & 75.1 \\
\hline Extended right hemihepatectomy & 96 & 3.0 \\
\hline Extended left hemihepatectomy & 101 & 3.2 \\
\hline Extended bisegmentectomy & 11 & 0.3 \\
\hline Extended right posterior sectionectomy & 6 & 0.2 \\
\hline Central LR (non-anatomic) & 25 & 0.8 \\
\hline Limited non-anatomical resection & 2137 & 67.5 \\
\hline
\end{tabular}


Table 5.

\begin{tabular}{l|cc}
\hline Complex LR & No of pts & $\%$ \\
\hline Criteria & & \\
\hline Maximum tumor diameter more than $100 \mathrm{~mm}$ & 139 & 4.4 \\
\hline More than 3 bilobar lesions & 127 & 4.0 \\
\hline Liver cirrhosis & 285 & 9.0 \\
\hline Trisectionectomy, right/left extended & & \\
(non-anatomical) hepatectomy, central LR & & \\
(anatomical/ non-anatomical), transversal & & \\
hepatectomy, two-stage hepatectomy, ALPPS & 275 & 8.6 \\
\hline Main bile ductresection & 169 & 5.3 \\
\hline Portal resection & 39 & 1.2 \\
\hline Inferior vena cava resection & 11 & 0.3 \\
\hdashline Other organ resection & 763 & 24.1 \\
\hline Number of simultaneous criteria & \multicolumn{2}{c}{} \\
\hline 1 & 1227 & 38.8 \\
\hline 2 & 220 & 7.0 \\
\hline 3 & 36 & 1.1 \\
\hline 4 & 7 & 0.2 \\
\hline TOTAL & 1495 & 47.2 \\
\hline
\end{tabular}

procedures increased overtime from 39.9\% (216 LRs) in $2000-2004$ to $50.3 \%$ in $2013-2016$ (511 LRs) ( $\mathrm{p}=0.02)$. The types of other organs resections performed simultaneously with LR are resumed in Table 6 .

Two hundred eighty-five LRs (9\%) were performed in cirrhotic patients.

Associated ethanol injection and thermal tumor ablation were used during 26 LRs (0.8\%) and $76 \mathrm{LRs}(2.4 \%)$, respectively.

Intraoperative ultrasound was used for diagnosis and resection guidance in $490 \mathrm{LRs}$ (15.5\%) and 137 LRs (4.3\%), respectively.

Total vascular exclusion was used in 49 LRs (1.5\%).

The median operative time was 180 minutes (mean 204 minutes; range 45-920). The median blood loss was $500 \mathrm{ml}$ (mean $850 \mathrm{ml}$; range 5009500). The transfusion rate was $41.6 \%$ (1316 operations).

\section{Surgical Outcome}

Overall complications rate was 40.1\% (1270 LRs) and major morbidity rate was $13.2 \%$ (418 LRs). Among all liver-related complications, bile leak was the most frequent (876 LRs; $27.7 \%$ ), followed by ascites (624 LRs; 19.7\%)
Table 6. Associated resections during LRs for focal liver lesions

\begin{tabular}{lccc}
\hline Associated resections during LR & No of pts & $\%$ \\
\hline Associated organ resection & 763 & 24.1 \\
\hline Liver resection associated with colorectal & & \\
resection & 182 & 5.8 \\
\hline Associated resection of common bile duct & 169 & 5.3 \\
\hline Associated portal vein resection & 39 & 1.2 \\
\hline Associated resection of inferior vena cava & 11 & 0.3 \\
\hline
\end{tabular}

Table 7. All liver-related complications recorded after LR

\begin{tabular}{lcc}
\hline Liver-related complications & No of LRs & $\%$ \\
\hline Bile leak & 876 & 27.7 \\
\hline Ascites & 624 & 19.7 \\
\hline Cut surface abcesses & 354 & 11.2 \\
\hline Liverfailure & 95 & 3.0 \\
\hline Hemoperitoneum & 46 & 1.5 \\
\hline Cut surfacehaematoma & 28 & 0.9 \\
\hline Localizedlivernecrosis & 17 & 0.5 \\
\hline Angiocholitis & 8 & 0.3 \\
\hline Portal veinthrombosis & 7 & 0.2 \\
\hline Arterial thrombosis & 5 & 0.1 \\
\hline Veingraftthrombosis & 2 & 0.1 \\
\hline
\end{tabular}

and cut-surface abscesses (354 LRs; 11.2\%) (Table 7).

Among major complications, cut-surface abscess was the most frequent complication after LR (44 LRs; 1.4\%) (Table 8).

Overtime, the major complications rates decreased from $14.7 \%$ (80 out of $541 \mathrm{LRs}$ ) in 2000-2004 to $11.7 \%$ (119 out of $1016 \mathrm{LRs}$ ) in 2013-2016 $(\mathrm{p}=0.05)$.

Overall, mortality rate was $4.2 \%$ (127 pts). There were not significantly statistical differences in mortality rates over the 4 periods of time $(p=0.6)$.

\section{Discussion}

The first documented LR was performed in the $\mathrm{XVII}^{\text {th }}$ century by Hildanus for liver trauma and the first elective LR was done by Langenbuch in 1888 (15). The first steps toward establishing the techniques of liver resection were performed at the beginning of the $6^{\text {th }}$ decade of the $\mathrm{XX}^{\text {th }}$ century, by surgeons like Honjo I (right hepatectomy; 1950) (16), 
Table 8. Dindo-Clavien classification of major complications after liver resection (LR)

\begin{tabular}{|c|c|c|c|c|c|c|c|}
\hline \multirow[t]{2}{*}{ Organ or System / Main complication } & \multicolumn{5}{|c|}{ Dindo-Clavien grade } & \multirow[b]{2}{*}{ TOTAL } & \multirow[b]{2}{*}{$\%$} \\
\hline & IIIA & IIIB & IVA & IVB & V & & \\
\hline \multicolumn{8}{|l|}{ Liver } \\
\hline Cut surface abscesses & 41 & 3 & 0 & 0 & 0 & 44 & 1.4 \\
\hline Hemoperitoneum & 0 & 21 & 0 & 0 & 6 & 27 & 0.9 \\
\hline Liver failure & 0 & 0 & 6 & 0 & 13 & 19 & 0.6 \\
\hline Bile leakage & 16 & 2 & 0 & 0 & 0 & 18 & 0.6 \\
\hline Ascitis & 14 & 1 & 0 & 0 & 0 & 15 & 0.5 \\
\hline Localized liver necrosis & 1 & 3 & 0 & 0 & 0 & 4 & 0.1 \\
\hline Hepatic artery thrombosis & 0 & 2 & 0 & 0 & 1 & 3 & 0.1 \\
\hline Portal vein thrombosis & 0 & 1 & 0 & 0 & 0 & 1 & 0.0 \\
\hline \multicolumn{8}{|l|}{ Lung } \\
\hline Pleural effusion & 32 & 1 & 0 & 0 & 0 & 33 & 1.0 \\
\hline Respiratory failure & 0 & 0 & 14 & 0 & 11 & 25 & 0.8 \\
\hline Bronchial pneumonia & 0 & 0 & 0 & 0 & 1 & 1 & 0.0 \\
\hline \multicolumn{8}{|l|}{ Digestive system } \\
\hline Colorectal fistula & 0 & 10 & 0 & 0 & 0 & 10 & 0.3 \\
\hline Perforated ulcer & 0 & 3 & 0 & 0 & 0 & 3 & 0.1 \\
\hline Small bowel fistula & 2 & 1 & 0 & 0 & 0 & 3 & 0.1 \\
\hline Pancreatic fistula & 2 & 0 & 0 & 0 & 0 & 2 & 0.1 \\
\hline Bowel obstruction & 0 & 2 & 0 & 0 & 0 & 2 & 0.1 \\
\hline Upper digestive hemorrhage & 0 & 0 & 1 & 0 & 0 & 1 & 0.0 \\
\hline Gastric fistula & 0 & 1 & 0 & 0 & 0 & 1 & 0.0 \\
\hline \multicolumn{8}{|l|}{ Kidney } \\
\hline Kidney failure & 4 & 0 & 6 & 0 & 0 & 10 & 0.7 \\
\hline \multicolumn{8}{|l|}{ Cardiovascular system } \\
\hline Pulmonary embolism & 7 & 0 & 8 & 0 & 12 & 27 & 0.8 \\
\hline Acute pulmonary edema & 0 & 0 & 4 & 0 & 10 & 14 & 0.5 \\
\hline Acute coronary syndrome & 6 & 0 & 0 & 0 & 6 & 12 & 0.4 \\
\hline Cardiac arrest & 0 & 0 & 0 & 0 & 3 & 3 & 0.1 \\
\hline \multicolumn{8}{|l|}{ Neurologic system } \\
\hline Stroke & 0 & 0 & 6 & 0 & 4 & 10 & 0.3 \\
\hline \multicolumn{8}{|l|}{ Systemic complications } \\
\hline MODS & 0 & 0 & 2 & 4 & 51 & 57 & 2.0 \\
\hline Sepsis & 0 & 1 & 5 & 0 & 8 & 14 & 0.5 \\
\hline \multicolumn{8}{|l|}{ Other abdominal complications } \\
\hline Intra-abdominal abscess & 22 & 6 & 0 & 0 & 1 & 29 & 0.9 \\
\hline Evisceration & 7 & 6 & 0 & 0 & 0 & 13 & 0.4 \\
\hline Peritonitis & 0 & 11 & 0 & 0 & 0 & 11 & 0.3 \\
\hline Wound infection & 3 & 1 & 0 & 0 & 0 & 4 & 0.1 \\
\hline Wound bleeding & 2 & 0 & 0 & 0 & 0 & 2 & 0.1 \\
\hline TOTAL & 159 & 76 & 52 & 4 & 127 & 418 & 13.2 \\
\hline$\%$ & 5.2 & 2.3 & 1.5 & 0.1 & 4.2 & 13.2 & \\
\hline
\end{tabular}

Lortat-Jacob JL (right hepatectomy and because, at that time, the functional anatomy extended right hepatectomy; 1952) (17,18) and of the liver has not been fully elucidated, yet. A Couinaud C. (left hemihepatectomy; 1952) (19). major step forward was made by Claude However, these initial attempts to perform Couinaud who revealed, based on the intraanatomical liver resections would not be able hepatic portal distribution, that the liver to standardize the surgical techniques, contains 8 independent anatomical and func- 
tional units, called segments (20,21). This initial description of the liver segmentation is, probably, the most important milestone in the development of liver resection, representing the basis of modern functional and surgical liver anatomy (22), although it was further improved by Henri Bismuth (23), Claude Couinaud (24) and the International HepatoPancreato-Biliary Association in $2000(5,25)$. Furthermore, the Couinaud conception represented the cornerstone for introduction and development of all the types of liver resection techniques.

In Romania, Ioan Balacescu, Amza Jianu and Thoma Ionescu performed the first nonanatomic LRs at the beginning of the $\mathrm{XX}^{\text {th }}$ century (26). Fagarasanu carried out the first left hepatectomy in 1956 (27) and the first right hepatectomy was performed in 1958 by Burghele (28). In 1971, V. E. Bancu et al., who performed the first hepatectomies in Targu Mures, was the first Romanian surgeon who published a paper about the evolution of liver resection techniques toward anatomical hemihepatectomies (29). In 1975, Mihai Stancescu et al. published the first Romanian series of 41 LRs (performed between 1960 and 1974) (30). In the early '80s, Vladimir Fluture and Sergiu Duca performed experimental liver transplantation (31) (32). The first large series of LRs was reported in 2003 by Irinel Popescu et al., who presented the results of 445 LRs performed between 1997 and 2002 in Fundeni Clinical Institute (33). In the same center, there were performed for the first time in Romania the total vascular exclusion for major LRs (34), isolated resection of segment 1 (35), two-stage hepatectomy (36), ALPPS (Associating Liver Partition and PVL for Staged hepatectomy) (37) and the ultrasoundguided LR (38). Meanwhile, Ionel Campeanu introduced the extraglissonian approach for anatomical LRs (39) and performed anatomic ventral anterior hemisectionectomy (40).

Most authors consider that high-volume centers are those institutions where are performed more than $50 \mathrm{LRs}$ per year $(41,42)$. It is known that high-volume centers and high-volume surgeons correlate with improved outcomes after LR $(43,44)$.

Besides expertise in liver surgery, extensive experience in surgical oncology and gastrointestinal pathology and high-quality diagnostic and interventional radiology are crucial for a high-volume center.

The present series of $3165 \mathrm{LRs}$ is one of the largest reported in the literature, so far.

\section{Indications for $L R$}

In our series, the majority of resected liver lesions were malignant $(74.9 \%)$, similar to the previous reports (from the high-volume centers) on the indications of LR (45).

Despite improvements in chemoembolization, thermal tumor ablation and other treatment modalities, LR remains the procedure of choice for most primary liver tumors (25). Although liver transplantation is the best approach in selected patients with HCC [mainly those with liver cirrhosis and small HCCs (46)], due to the shortage of organs, this approach could not be applied to all these patients.

Another major indication for LR in malignant liver tumors is represented by colorectal liver metastases (CLMs) (47). In patients with CLMs, resection is considered the gold standard treatment offering the highest rates of overall survival $(48,49)$.

The better outcomes of patients undergoing LR for malignant liver tumors led to the extension of criteria for LR in such patients, thus increasing the number of hepatectomies performed for CLMs non-colorectal liver metastases and intrahepatic cholangiocarcinoma (50). Similar trends were observed in the present series, with a statistically significant higher incidence of LRs for such indications in the interval 2013-2016 than between 20002004.

Conversely, LR for benign lesions decreased overtime, especially for hemangiomas (who continue to represent the most frequently resected benign liver tumor). This decreased prevalence of LR for hemangioma could also be explained by the changing paradigm regarding the indications for its resection. 
Thus, in present, it is considered that hemangiomas should be resected when their maximum diameter exceeds $10 \mathrm{~cm}$ (and not 4$5 \mathrm{~cm}$ as it was recommended in the early 2000s) (51).

\section{Surgical Technique}

\section{Operative Approaches}

The main approach in our series was open, usually consisting in a bilateral subcostal incision with or without upward midline extension; $\mathrm{J}$ incision (52) or upper midline incision were seldom used. A thoracic extension was rarely necessary for bulky right hemiliver tumors invading the diaphragm. A J-incision is another way to gain good exposure to the whole liver with the advantage of extension into the thoracic cavity, if needed. Occasionally, an upper midline incision is sufficient for a minor hepatic resection such as a left lateral sectionectomy.

Despite initial concerns about bleeding, air embolism, tumor seeding (port site and peritoneal) and oncologic clearance, minimal invasive approach has been proven efficient in LR. Moreover, minimal invasive LRs insure shorter hospital stay, less analgesic require- ment and quicker oral intake, while complication rate is comparable to open LR (53). Although initially the laparoscopic approach was recommended in patients with small focal lesions (less than $5 \mathrm{~cm}$ ), limited number of tumors and favorable topography (segment 2, $3,4 \mathrm{~b}, 5$ or 6 ; distant to major vascular trunks) and who do not require vascular/ biliary reconstruction (54), in the last years, specialized centers performed on a larger scale major LRs by minimal invasive approach (55). By these reasons, in our center, beside the minor liver resections performed by minimally invasive approach, there were performed also right hepatectomies, either by laparoscopic or robotic approach (Fig. 3).

Usually, LR was preceded by liver mobilization; however, if the right hemiliver was occupied by a bulky tumor, an anterior approach without prior mobilization was preferred. In order to facilitate the hemi hepatectomies, the hanging maneuver described by Belghiti et al (56) was used whenever considered adequate by the surgeon. Frequently, during right hepatectomies, a modified hanging maneuver was used, consisting in passing the tape after complete
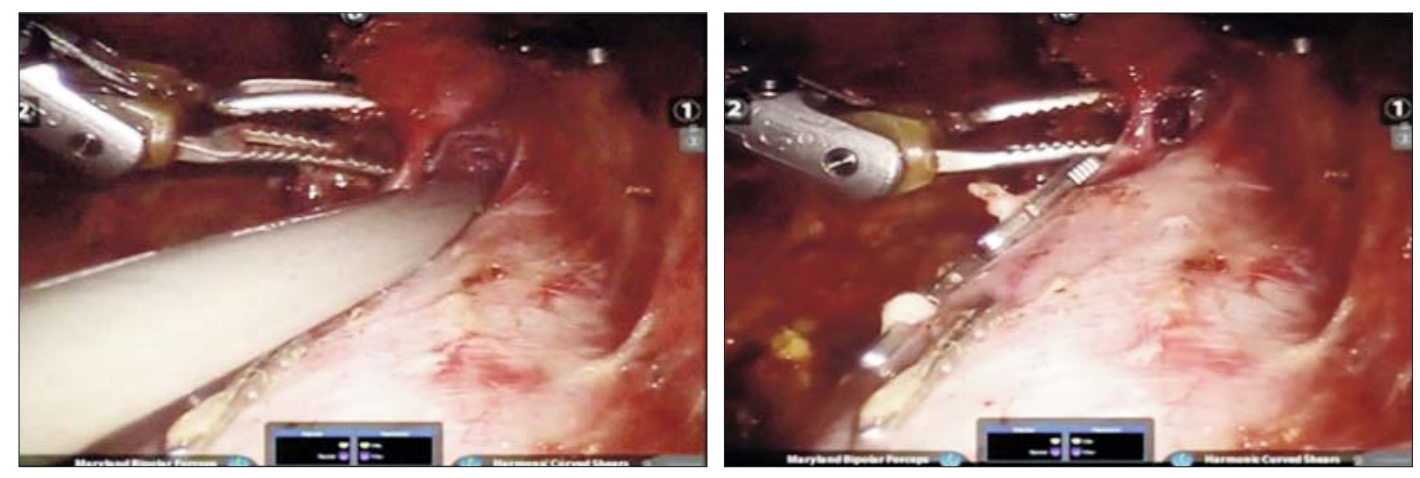

Figure 3. Robotic right hemihepatectomy for colorectal liver metastases

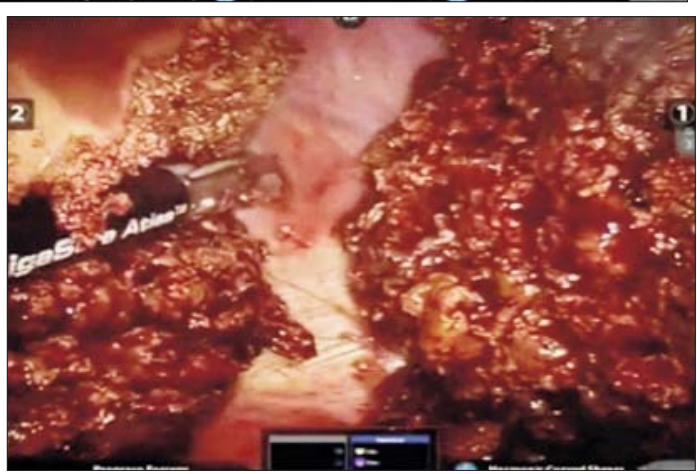


right hemiliver mobilization, sectioning the hepatocaval ligament and right small hepatic veins and exposing the right hepatic vein at its confluence with inferior vena cava, thus avoiding the bleeding risk from the blind blunt dissection in front of the IVC.

\section{Intraoperative Ultrasonography}

Intraoperative ultrasound (IOUS) remains an essential tool for hepatobiliary surgeons. The main advantages offered by IOUS are the improved detection of liver tumors and the possibility to guide and assist LR (57). Despite significant advancements in preoperative imaging, such as contrast-enhanced CT scan, MRI and FDG-PET, IOUS still provides essential diagnostic information during operation by detecting new lesions that were not revealed by preoperative imaging methods. The detection of additional tumors during the surgery often changes the scheduled surgical procedure and even the therapeutic management of the patient. IOUS may also assist the LR procedure, by delineating the resection area, guiding the line of transection, marking target vascular structures that should be resected or, by contrary, preserved (58). IOUS could also be used to assess the immediate results after LR, checking the remnant liver for proper vascular flow and tumor-clearance. Thus, IOUS increases the rate of complete tumor clearance increasing the chance of improved survival in patients with malignant liver tumors. In the present series, IOUS guidance was used in $137 \mathrm{LRs}$ (4.3\%) (either anatomical or non-anatomical).

\section{Methods for Parenchyma Transection}

Regarding the parenchyma transection methods, a recent randomized controlled trial, comparing four different transection methods used in LR, showed that the clamp crushing method remained the most efficient device in terms of resection time, blood loss, and blood transfusion rate, when compared with CUSA, hydrojet and the dissecting sealer. Moreover, this trial revealed that the clamp crushing method was also the least expensive (59). However, the choice of parenchyma transection method remains a matter of preference and skills on behalf of each surgical team and a matter of costeffectiveness for the institution.

\section{Intraoperative Blood Loss Control}

Despite the recent advances in surgical and anesthetic techniques, blood transfusion is still required in $10-33 \%$ of patients undergoing elective LRs $(60,61)$. The need for blood transfusions depends on the amount of blood loss, which is increased by liver cirrhosis or advanced steatosis, as well as by the complexity of LR. In the present series, the overall transfusion rate was $41.6 \%$, slightly higher in comparison to the published data. This could be explained by the relative higher number of patients with liver cirrhosis or requiring major hepatectomies (almost 30\%), that were included in this series. Moreover, in this study, emergency LRs (performed for liver trauma and ruptured HCCs or adenomas) were included.

Major bleeding and the subsequent requirements for blood transfusion have been shown to increase the post-operative morbidity and mortality $(62,63)$. Perioperative blood transfusions are also associated with higher recurrence rates and lower survival rates after resection of malignant liver tumors, especially in HCC (64).

Similar to other centers (65), in our institution, vascular control methods (Pringle maneuver, total vascular exclusion) were implemented, to reduce the blood loss and decrease the rate of blood transfusions. In patients included in this series, mostly intermittent (15 to 20 minutes, with 5 minutes breaks) Pringle maneuver was used. Hemihepatic clamping (half-Pringle maneuver), that interrupts the vascular inflow selectively to the hemiliver that is to be resected (66), was used only in few situations. Ischemic preconditioning (devised for protection against subsequent sustained ischemia-reperfusion injury) (67) was also seldom performed. Total vascular exclusion, combining total inflow and outflow occlusion of the liver (68), was performed in selected cases with high risk of bleeding during LR and tolerance to the significant hemodynamic changes (49 LRs; $1.5 \%$ ) (69). The prompt deployment of this maneuver in 
case of torrential hemorrhage during LR was often considered a life-saving procedure. The modified total vascular exclusion, consisting in inflow occlusion associated with extra parenchymal control of hepatic veins, was used in few cases. Lowering the central venous pressure below $5 \mathrm{~cm} \mathrm{H} 2 \mathrm{O}$, in order to decrease the backflow bleeding during LR (70), was not routinely carried out, representing another potential explanation for the relative higher transfusion rate.

In patients with benign lesions, when significant blood loss was anticipated, the autologous blood recovery system (Cell Saver ${ }^{\circledR}$ ); Haemonetics) was used, to decrease the need for blood transfusion and improve the short-term outcomes.

The routine use of fibrin sealant for bleeding control and lowering the risk of postoperative bile leak has not been supported by prospective randomized trials although it has been quite extensively used by many centers $(71,72)$. However, in this series, such methods were used, especially when high risk of bleeding and/or bile leak was estimated. Recently, in such instances, autologous fibrin sealant technology (Vivostat@; Alleroed) was employed.

Even though the routine use of abdominal drainage after hepatic surgery has been challenged and many centers do not drain after LR anymore (73) (74), we routinely used drains in such operations, supporting this "old-fashioned" policy.

\section{Extension of LR}

In the first years of modern era of liver surgery, major hepatectomies were extensively used to resect malignant liver tumors (3). Because afterward it was observed that the only independent prognostic factors correlated with increased morbidity and mortality were blood loss and the number of resected liver segments, a trend toward replacing major hepatectomies with limited liver resections was observed (3). Thus, in the last decade, most centers favor parenchyma sparing LRs instead of major LRs. A similar trend is observed in the present series, with a signifi- cant decrease in proportion of major LRs overtime $(23.8 \%$ in $2000-2004$ vs. $16.8 \%$ in 2013-2016, $p$ value $=0.04)$. Besides the lower morbidity and mortality rates associated with parenchyma sparing hepatectomies, another advantage of this approach is the increased likelihood of performing repeat LRs for recurrent liver malignancies. This policy to perform repeat LRs for recurrent hepatic malignancies represents one of the most important modalities to significantly improve overall survival in patients with CLMs and intrahepatic cholangiocarcinoma $(75,76)$.

The performance of parenchyma sparing hepatectomies was facilitated by the advent of IOUS. This method allows performing segmental oriented anatomical LRs, thus avoiding major hepatectomies. The main benefit of this approach was observed in cirrhotic patients with $\mathrm{HCC}$, because the replacement of major hepatectomies by the limited anatomical LRs decreased the risk of postoperative liver failure and increased the resectability rates.

\section{Type of $L R$}

Although the debate regarding the preferred type of LR (anatomical vs. non-anatomical) still continues, in present, several conclusions have been established.

Because it was clearly proven that in $\mathrm{HCC}$ the tumor spread occurs through portal system, it is obvious the necessity to remove the entire liver segment where the tumor is located $(77,78)$. Thus, the potential tumor cells, spread (via portal branches) within different parts of the tumoral liver segment, will be removed, decreasing the risk of recurrence. The use of IOUS is of tremendous importance to achieve such segmental-oriented LRs and the higher number of ultrasound-guided LRs reported in this series between 2013 and 2016 is a consequence of the devotion to this procedure.

In contrast, in patients with CLMs, multiple comparative studies investigating the results achieved by anatomical vs. nonanatomical LRs revealed similar results regardless the type of hepatectomy (79) (80). Similarly, in patients with intrahepatic cholangiocarcinoma, there is no evidence 
that the type of LR influence the long-term outcomes.

By these reasons, in our center, nonanatomical LRs are favored in patients presenting other liver tumors but HCC. Because less than $20 \%$ of patients in this series underwent LR for HCC, the percentage of anatomical $L_{\mathrm{S}}$ in the entire series was lower than $25 \%$.

\section{Resection Margins}

For liver malignancies, the achievement of a negative resection margin larger than $1 \mathrm{~cm}$ was recommended, traditionally. However, the evidence of the last two decades revealed that even narrow resection margins will enable similar overall survival rates if they are negative ( $\mathrm{R} 0$ resections).

As such, in patients with HCC, several studies revealed that resection margins less than $1 \mathrm{~cm}$ did not correlate with significantly higher recurrence rates (81-83). However, whenever possible, in patients with $\mathrm{HCC}$ should be performed R0 segmental-oriented hepatectomies.

Similarly, in CLMs, most authors consider that the margin width does not influence the long-term outcomes, as long as a negative margin $(\mathrm{R} 0)$ is achieved $(84,85)$. These results are explained by the extensive use of efficient adjuvant chemotherapy in these patients. Moreover, in the last years, for CLMs adjacent to intrahepatic vascular structures that should not be resected, CLMs-vessel detachment R1 vascular margin (R1Vasc) was performed (86). Surprisingly, a recent paper revealed the equivalence between $\mathrm{R} 1$ vascular resections and R0 LRs (87). Similar conclusions were presented by other recent studies, revealing that an aggressive approach consisting in combined chemotherapy and repeat surgery could achieve similar overall survival rates in patients undergoing R1 LRs vs. R0 hepatectomies (88).

\section{Complex LR}

In this study, almost half of LRs were complex $(47.2 \%)$, meaning that patients often were referred to surgery in advanced stages. The performance of such complex operations requires highly trained surgical teams, experienced not only in liver surgery, but also in lower GI and upper GI surgery. By this reason, patients with such complex presentations of liver tumors should always be evaluated by a multidisciplinary team, in a highly-specialized center in HPB and digestive surgery.

In present series, the proportion of complex LRs significantly increased overtime, from $39.9 \%$ in $2000-2004$ to $50.3 \%$ in $2013-2016$ (p value $=0.02)$. That reflects that the experience gained overtime in specialized high-volume centers makes possible the use and development of more sophisticated liver resection techniques and the association of hepatectomy with other surgical procedures.

\section{Increase of Resectability}

In the present series were included all the strategies aiming to improve the resectability rates in patients with otherwise unresectable liver tumors. Based on the current definition of resectability of liver tumors, the only contraindications for LR are the impossibility to achieve an $\mathrm{R} 0$ resection and preserve a sufficient volume of liver parenchyma to avoid postoperative liver failure (25-30\% of TLV in patients with normal liver parenchyma or $40 \%$ of TLV in patients with chronic hepatopathy or liver cirrhosis) (89) (90).

Currently available strategies to achieve complete clearance of the liver are:

- LR after embolization/ligation of one of the main branches of the portal vein. PVL/embolization usually induces the hypertrophy of the contralateral hemiliver, allowing subsequent performance of a curative-intent LR in patients whose initial FLR was less than $25-30 \%$ of TLV (91). The main drawbacks of this approach are insufficient FLR hypertrophy and tumor progression before the achievement of sufficient FLR hypertrophy, which preclude LR in up to $40 \%$ of cases (92) (91). In our experience, $26 \mathrm{pts}$ (1.3\%) benefited from PVL, out of which 21 $(1.2 \%)$ were for colorectal liver metastasis. Resectability rate was $55 \%$, similar to 
those presented in other series.

- Two-stage hepatectomy (93), recommended in multiple bilobar CLMs, consists in two subsequent hepatectomies. During the first operation are resected the metastases from the less affected hemiliver and, sometimes (when the volume of this hemiliver is less than $25-30 \%$ of TLV), is performed ligation of the contralateral portal branch. The second stage is usually performed 4-8 weeks later (when the volume of FLR increased to more than $25-30 \%$ of TLV) and consists in resection of the bulk metastatic burden from the contralateral hemiliver (usually by a hemihepatectomy or trisectionectomy) $(36,93,94)$. The drawbacks are the necessity of two operations (each associated with specific morbidity and mortality) and the failure to perform the second stage due to tumor progression in $19-24 \%$ patients $(94,93)$. In the present series, there 5 such procedures were performed, 3 with PVL and 2 without.

- ALPPS (Associating Liver Partition and PVL for Staged hepatectomy) procedure is a novel surgical technique that aims the more rapid and robust hypertrophy of the FLR. It consists in two operations; during the first stage is performed right portal branch ligation and in-situ splitting of the liver parenchyma along the left intersectional plane; in the second stage are resected the right hepatic artery, the right hepatic duct and the RHV and MHV, followed by completion of the right trisectionectomy. After the initial operation, the volume gain usually exceeds $75 \%$ and this important hypertrophy of FLR occurs in 7-10 days. In the present series one patient with primary hepatic lymphoma underwent this approach, without postoperative complications. However, the limitations of this technique are related to the increased rates of major morbidity (up to 40\%) and mortality (up to 12\%) (95)

- Multiple liver resections represent an alternative to the two stage hepatectomy, especially in patients with bilobar liver tumors. The strategy consists in avoidance of major LRs $(<5 \%)$, replacing them with multiple non-anatomical resections,

Figure 4. Non-anatomical LR of
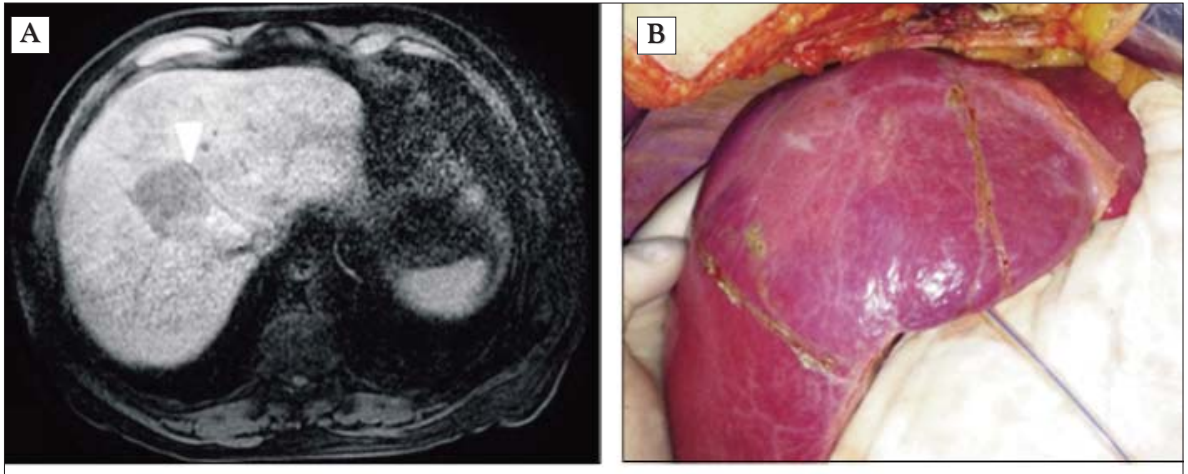
segments IV, V and VIII with segmental resection of middle hepatic vein (MHV). A. deep-located hepatocellular carcinoma (HCC) in segment VIII compressing MHV (arrow head). B. Resection area marked with electrocautery; C. Remnant liver; D. Resected specimen
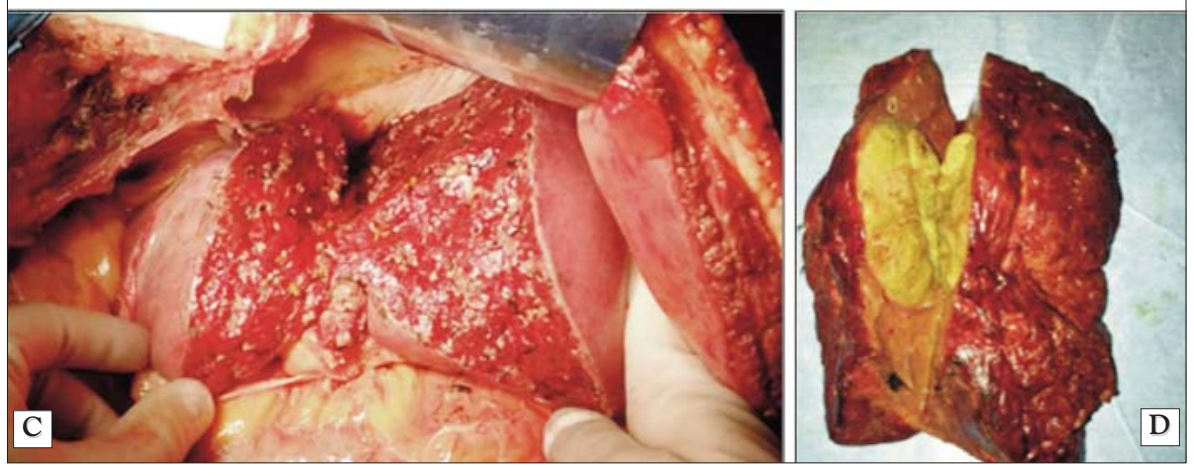
or segmental oriented minor LR associated with minor non-anatomical resections (Fig. 4). The main criticism is represented by narrow resection margins and even a higher incidence of $\mathrm{R} 1$ resections (96).

- Acceptance of resection margins less than $1 \mathrm{~cm}$ and even $\mathrm{R} 1$ vascular resections also increases the resectability rates, especially in patients with multiple, bilobar liver tumors.

- Conversion to resectability by tumor shrinkage following chemotherapy is useful mainly in patients with large CLMs.

- Replacement of major anatomical hepatectomies with non-anatomical limited LRs. This approach is usually recommended in patients with liver metastases or intrahepatic cholangiocarcinoma. Thus, whenever feasible, hemihepatectomy associated with partial resection of the adjacent section was preferred instead of a trisectionectomy and right posterior sectionectomy associated with partial resection of the anterior section replaced the right hepatectomy. For centrally located tumors (segments 4,5 and 8), an alternative to the central hepatectomy (trisegmentectomy 4 , $5,8)$ was a non-anatomical LRs of the tumors located in these segments (Fig. 5). The performance of such a hepatectomy, which involves segmental resection of the MHV, requires IOUS to detect the presence of compensatory collateral venous circulation to the RHV and LHV (97). By these techniques, as much as possible liver parenchyma is preserved, enabling LR in some patients considered unresectable by conventional LR techniques.

- LR associated with in-situ ablation of less than $3 \mathrm{~cm}$ tumors located in the remnant parenchyma significantly improves survival in comparison with palliative treatment.

\section{Postoperative Outcome}

For a long period, LR has been associated with high morbidity and mortality rates. Due to the progresses in liver surgery, anesthesiology and intensive care therapy, the short-term outcomes improved during the last three decades. However, the morbidity rates vary among different centers, ranging between $16.2 \%$ and $47.7 \%(98,99)$. This large range is partially due to the heterogeneity of the published series,

Figure 5. Non-anatomical multiple LR for multiple bilobar hemangioendotelioma (13 lesions). A, B. Resection areas marked with electrocautery; C, D Remnant liver

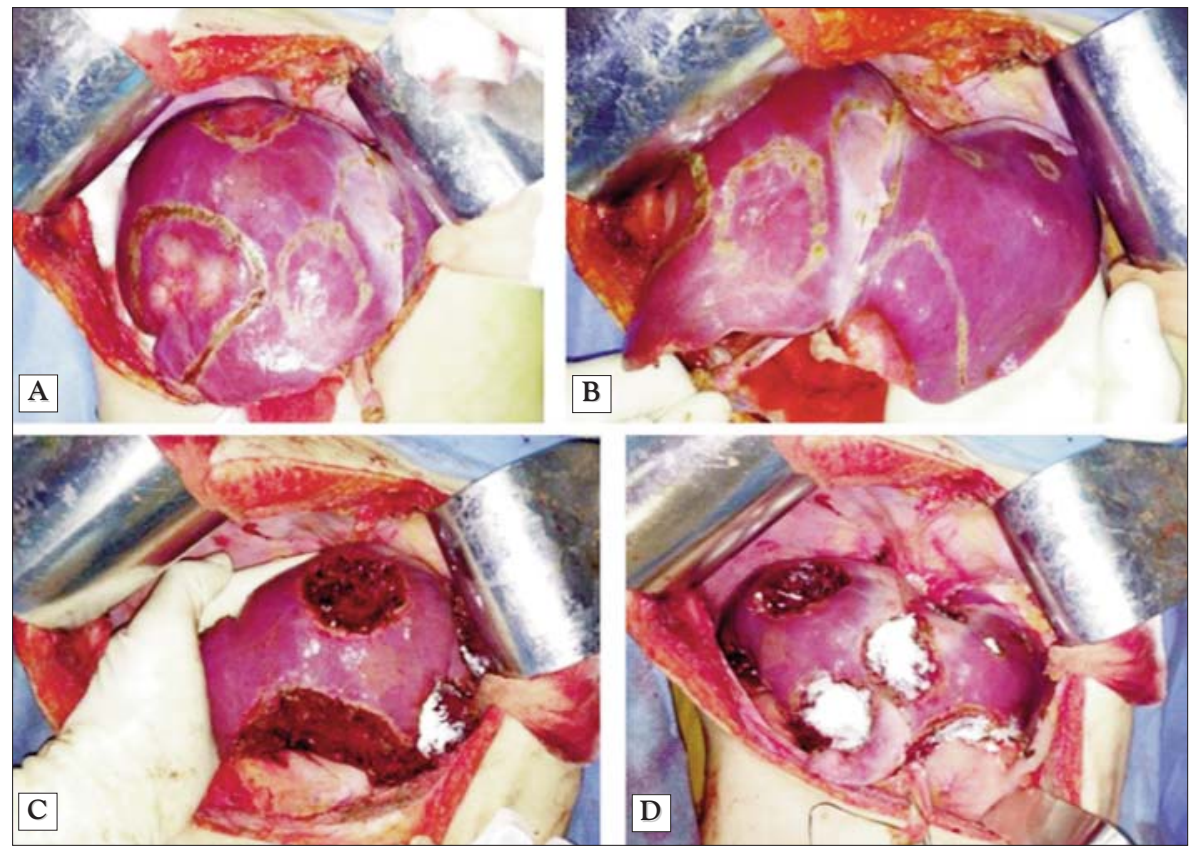


with major differences in indications, extension of LRs, number of patients with liver cirrhosis and volume-load of the center.

In present series, the overall morbidity was $40.1 \%$ and major complications rate was $13.2 \%$, similar to those reported by other highvolume centers during the last two decades. However, the major complications rates decreased from $14.7 \%$ (80 out of 541 LRs) in 2000-2004 to $11.7 \%$ (119 out of $1016 \mathrm{LRs}$ ) in 2013-2016 ( $\mathrm{p}=0.05)$, as a consequence of the increased experience with LRs of both surgical and anesthesia teams.

Among all liver-related complications, bile leaks were the most frequent (27.7\%). Among major complications, cut-surface abscesses were the most frequent and most severe complications after LR (1.4\%). Liver failure was the most common liver-related complication leading to death: out of $95 \mathrm{LRs}$ complicated with liver insufficiency, $54 \mathrm{pts}$ died (56.8\%): 13 pts with liver failure only and 41 with MSOF induced by liver failure. Of note, one patient with liver failure after LR was transplanted with a whole liver graft.

Complex LR was the main factor influencing the postoperative outcome, with major complication and mortality rate of $16.9 \%$ and $6.6 \%$, respectively, compared to $8.6 \%$ and $2.2 \%$, respectively, in patients undergoing noncomplex LRs ( $\mathrm{p}=0.01$ and $\mathrm{p}<0.01$, respectively). In our opinion, the complexity of LR should always be considered when analyzing the results of a certain series.

The mortality rate after $\mathrm{LR}$ varies from $1.5^{-}$ $3.5 \%$ in high-volume centers, to $8-24 \%$ in low-volume ones $(100,101)$. In our experience, the 30-day and 90-day mortality rates were $3.1 \%$ and $4.2 \%$, respectively, which is similar to other high-volume centers.

\section{New Technologies in LR}

Technology is an intricate part of the development of liver surgery, starting with preoperative imaging, intraoperative tools, and postoperative intensive care treatments. In preoperative imaging, a recent development that is worth mentioning is the advanced planning tool

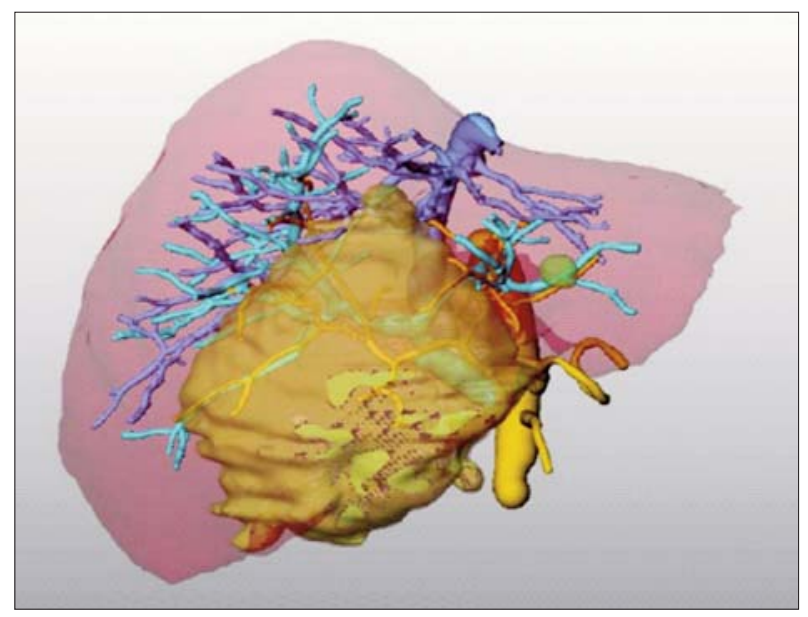

Figure 6. MeVis $® 3 \mathrm{D}$ reconstruction for large cholangiocarcinoma

that provide high-resolution color-coded 3D visualization of the liver parenchyma and its vessels, with corresponding liver segmentation. Moreover, this tool simulates LR scenarios, evaluating the risks of cutting at a given point in the liver. Applied to tumor resection, the software optimizes the shape of the transection plane and allows deciding which vessels need to be reconstructed in order to avoid liver ischemia or congestion. This system was recently implemented in our practice $(\mathrm{MeVis} \mathbb{R}$; $\mathrm{MeVis}$ Medical Solutions AG) optimizing the planning of $23 \mathrm{LRs}$ performed for malignant lesions (Fig. 6).

A novel device using real-time intraoperative navigation technology (CAScination®: Cascination $\mathrm{AG}$ ) provides integration of pre-operative $3 \mathrm{D}$ liver models, surgical instruments and intraoperative ultrasound imaging, optimizing the surgical producers, such as LRs or thermal ablation. This device was recently introduced in our surgical practice, guiding the LR in 4 patients.

\section{Conclusion}

LR involves complex surgical techniques requiring extensive anatomy and radiology knowledge, surgical expertise, adequate endowments and also proper anesthesia and intensive care therapy.

The wide range of operative techniques, instruments and devices involved in LR means that currently there is no clearly superior 
established method. The use of a particular technique is determined mainly by the surgeon's preference and by the particular conditions of LR and liver parenchyma status. Thus, many surgeons prefer clamp crushing for parenchyma transection and intermittent Pringle maneuver for vascular control. Nevertheless, liver surgeons should be familiar with all liver resection techniques, vascular control and parenchyma transection methods, because the need to employ alternative ways of performing hepatectomy may often occur.

The advent of surgical and radiological methods able to increase the volume of FLR led to increased resectability rates, over the last two decades. Moreover, modern chemotherapy also contributes to further improvement in resectability rates, by liver tumors shrinkage. the modern chemotherapy protocols entered the clinical practice, the resection margin have become of secondary importance.

The current trend is to perform parenchyma sparing hepatectomies, thus allowing the safe performance of repeat LRs for recurrent liver malignancies. This surgical approach leads to the reduction of morbidity and mortality rates, while increasing overall survival of patients with malignant liver tumors.

LRs should be carried out in specialized high-volume centers, thus achieving lower morbidity and mortality rates. This short-term outcomes improve overtime, due to the greater experience gained by high-volume teams and surgeons.

\section{References}

1. Foster JH, Berman MM. Solid liver tumors. Major Probl Clin Surg 1977; 22: 1- 342.

2. Belghiti J, Hiramatsu K, Benoist S, Massault P, Sauvanet A, Farges 0. Seven hundred forty-seven hepatectomies in the 1990s: an update to evaluate the actual risk of liver resection. J Am Coll Surg. 2000; 191(1):38-46.

3. Jarnagin WR, Gonen M, Fong Y, DeMatteo RP, Ben-Porat L, Little S, et al. Improvement in perioperative outcome after hepatic resection: Analysis of 1803 consecutive cases over the past decade. Ann Surg. 2002;236(4):397-406; discussion 406-7.

4. Imamura H, Seyama Y, Kokudo N, Maema A, Sugawara Y, Sano K, et al. One thousand fifty-six hepatectomies without mortality in 8 years. Arch Surg. 2003;138(11):1198-206; discussion 1206.

5. Terminology Committee of the IHPBA. Terminology of liver anatomy and resections. HPB Surg. 2000;2:333-9.

6. Lin TY. A simplified technique for hepatic resection: the crush method. Ann Surg. 1974;180(3):285-90.
7. Nagano $\mathrm{Y}$, Matsuo $\mathrm{K}$, Kunisaki C, Ike H, Imada T, Tanaka K, et al. Practical usefulness of ultrasonic surgical aspirator with argon beam coagulation for hepatic parenchymal transection. World J Surg. 2005; 29(7):899-902.

8. Romano F, Franciosi C, Caprotti R, Uggeri F, Uggeri F. Hepatic surgery using the Ligasure vessel sealing system. World J Surg. 2005;29(1): 110-2.

9. Kim J, Ahmad SA, Lowy AM, Buell JF, Pennington LJ, Soldano DA, et al. Increased biliary fistulas after liver resection with the harmonic scalpel. Am Surg. 2003;69(9):815-9.

10. Weber JC, Navarra G, Jiao LR, Nicholls JP, Jensen SL, Habib NA. New technique for liver resection using heat coagulative necrosis. Ann Surg. 2002;236(5):560-3.

11. Fasulo F, Giori A, Fissi S, Bozzetti F, Doci R, Gennari L. Cavitron Ultrasonic Surgical Aspirator (CUSA) in liver resection. Int Surg. 1992; 77(1):64-6.

12. Schemmer P, Friess H, Hinz U, Mehrabi A, Kraus TW, Z'graggen K, et al. Stapler hepatectomy is a safe dissection technique: analysis of 300 patients. World J Surg. 2006;30(3):419-30.

13. Takayama T, Makuuchi M, Kubota K, Harihara Y, Hui AM, Sano K, et al. Randomized comparison of ultrasonic vs clamp transection of the liver. Arch Surg. 2001;136(8):922-8.

14. Dindo D, Demartines N, Clavien PA. Classification of surgical complications: a new proposal with evaluation in a cohort of 6336 patients and results of a survey. Ann Surg. 2004;240(2):205-13.

15. Langenbuch C. Ein Fall von Resecktion eines linksseitigen Schnurlappens der Leber. Berl Klin Wochenschr 1888;25:37.

16. Honjo I. Total resection of the right lobe of the liver. Shujutsu. 1950; 4:345-349.

17. Lortat-Jacob JL, Robert HG. Well defined technic for right hepatectomy. Presse Med. 1952;60(26):549-51.

18. Lortat-Jacob JL, Robert HG, Henry C. Excision of the right lobe of the liver for a malignant secondary tumor. Arch Mal Appar Dig Mal Nutr. 1952;41(6):662-7.

19. Couinaud C. Segmental and lobar left hepatectomies; studies on anatomical conditions. J Chir (Paris). 1952;68(11):697-715. French

20. Couinaud C. Liver lobes and segments: notes on the anatomical architecture and surgery of the liver. Presse Med. 1954;62(33):709-12. French

21. Couinaud C. Le foie. Paris: Masson; 1957.

22. Bismuth $\mathrm{H}$, Eshkenazy $\mathrm{R}$, Arish A. Milestones in the evolution of hepatic surgery. Rambam Maimonides Med J. 2011;2(1):e0021. doi: 10.5041/RMMJ.10021.

23. Bismuth $\mathrm{H}$. Surgical anatomy and anatomical surgery of the liver. World J Surg. 1982:6(1):3-9.

24. Couinaud C. Liver anatomy: portal (and suprahepatic) or biliary segmentation. Dig Surg. 1999;16(6):459-67.

25. Strasberg SM. Nomenclature of hepatic anatomy and resections: a review of the Brisbane 2000 system. J Hepatobiliary Pancreat Surg. 2005;12(5):351-5

26. Setlacec D. Medicina romaneasca - medicina europeana, 1859-1916. Editura Medicala; 1995.

27. Fagarasanu I, Aloman D. Aspecte teoretice si practice ale rezectiilor de ficat. Chirurgia, 1960;4:495-506.

28. Popescu I, sub redactia. Chirurgia ficatului. Editura Universitară "Carol Davila“" (Bucuresti), 2004, pag. 663-742.

29. Bancu VE, Papai Z, Csiky N, Hornyak B, Kesztenbaum E, Balint E, et al. Evolution of hepatectomy toward total lobar controlled hepatectomy in the Surgical Clinic I of Tîrgu Mures. Chirurgia (Bucur). 1971;20(12): 1075-82. Romanian

30. Stancescu M, Popovici A, Cristea I. Consideratii asupra unui număr de 41 rezectii hepatice. Chirurgia 1975;23(2):105-112.

31. Fluture V, Nicola T, Dinulescu T, Laitin S, Dan I, Chiru A, et al. A technic of experimental heterotopic hepatic transplantation. Rev Chir Oncol Radiol O R L Oftalmol Stomatol Chir. 1981;30(2):123-33. Romanian

32. Duca S. Liver transplantation. Liver transplantation. Experimental aspects Rev Chir Oncol Radiol O R L Oftalmol Stomatol Chir. 
1981;30(6):449-58. Italian

33. Popescu I, Tulbure D, Ionescu M, Ciurea S, Brasoveanu V, Pietrareanu D, Boeti P, Hrehoret D, Boros M. Liver resection: indication, tehnique results - Analysis of a 445 case serie. Chirurgia (Bucur). 2003;98(1): 17-35. Romanian

34. Popescu I, Tulbure D. Total vascular exclusion in liver surgery. Chirurgia (Bucur). 1996;45(3):111-8.

35. Popescu I, Ciurea S, Romanescu D, Boros M. Isolated resection of the caudate lobe: indications, technique and results. Hepatogastroenterology. 2008;55(84):831-5.

36. Popescu I, David L, Brasoveanu V, Boros M, Hrehoret D. Two-stage hepatectomy: an analysis of a single center's experience. Magy Seb. 2006;59(3):184-9.

37. Alexandrescu S, Stoica L, Grigorie R, Tomescu D, Dobrea C Popescu I, et al. Primary hepatic lymphoma resected by ALPPS procedure (Associating Liver Partition and Portal Vein Ligation for Staged Hepatectomy). J. Transl. Med. Res 2016;21(2):153-8.

38. Botea F, Nicolaescu D, Onofrei A, Barcu A, Picu N, Popescu I. Intraoperative ultrasound guided liver resection: single center experience. J. Transl. Med. Res. 2017. In press.

39. Campeanu I. Rezectiile hepatice extraglissoniene. Sub redactia: Popescu I. Chirurgia ficatului. Bucuresti: Editura Universitară "Carol Davila“; 2004. p. 663-742.

40. Campeanu I, Petrescu R, Dragan C, Pruna M, Corneci D, Buia F, et al. Sinistromedian (supra)hepatic resection. A putting up-to-date of Hjortsjo hepatic segmentation. Chirurgia (Bucur). 2005;100(4): 349-56

41. Asiyanbola B, Chang D, Gleisner AL, Nathan H, Choti MA, Schulick $\mathrm{RD}$, et al. Operative mortality after hepatic resection: are literaturebased rates broadly applicable? J Gastrointest Surg. 2008;12(5): 842-51. doi: 10.1007/s11605-008-0494-y. Epub 2008 Feb 12.

42. Csikesz NG, Simons JP, Tseng JF, Shah SA. Surgical specialization and operative mortality in hepato-pancreaticobiliary (HPB) surgery. J Gastrointest Surg. 2008;12(9):1534-9. doi: 10.1007/s11605008-0566-z. Epub 2008 Jul 9.

43. BirkmeyerJ, Siewers AE, Finlayson EV, Stukel TA, Lucas FL, Batista I, et al. High volume and surgical mortality in the United States. N Engl J Med. 2002;346(15):1128-37.

44. Eppsteiner R, Csikesz NG, Simons JP, Tseng JF, Shah SA. High volume and outcome after liver resection: surgeon or center? Gastrointest Surg. 2008;12(10):1709-16; discussion 1716. doi: 10.1007/s11605-008-0627-3. Epub 2008 Aug 13.

45. Dimick JB, Cowan JA Jr, Knol JA, Upchurch GR Jr. Hepatic resection in the Unites States: indications, outcomes, and hospital procedural volumes from a nationally representative database. Arch Surg. 2003 138(2):185-91

46. Mazzaferro V, Chun YS, Poon RTP, Schwartz ME, Yao FY, Marsh JW, et al. Liver transplantation for hepatocellular carcinoma. Ann Surg Oncol. 2008;15(4):1001-7. doi: 10.1245/s10434-007-9559-5. Epub 2008 Jan 31.

47. Choti MA, Sitzmann JV, Tiburi MF, Sumetchotimetha W, Rangsin R, Schulick $\mathrm{RD}$, et al. Trends in long-term survival following liver resection for hepatic colorectal metastases. Ann Surg. 2002; 235(6): 759-66.

48. Blackham AU, Swett K, Levine EA, Shen P. Surgical management of colorectal cancer metastases to the liver: multimodality approach and a single institutional experience. Colorectal Cancer. 2013;2(1):73-88.

49. Popescu I, Ionescu M, Alexandrescu S, Ciurea S, Hrehoret D, Sârbu-Boeti $P$, et al. Surgical treatment of liver metastases from colorectal cancer. Chirurgia (Bucur). 2006;101(1):13-24.

50. Minagawa M, Makuuchi M, Torzilli G, Takayama T, Kawasaki S, Kosuge $T$, et al. Extension of the frontiers of surgical indications in the treatment of liver metastases from colorectal cancer: Iong-term results. Ann Surg. 2000;231(4):487-99.

51. Giuliante F, Ardito F, Vellone M, Giordano M, Ranucci G, Piccoli M, et al. Reappraisal of surgical indications and approach for live hemangioma: single center experience on 74 patients. Am J Surg.
2011;201(6):741-8.

52. Kawasaki S, Makuuchi M. Incision for hepatectomy. In, Lygidakis NJ, Makuuchi M, (eds). Pitfalls and complications in the diagnosis and management of hepatobiliary and pancreatic diseases Stuttgart: George Thieme; 1993: 86-88.

53. Morino M, Morra I, Rosso E, Miglietta C, Garrone C. Laparoscopic vs open hepatic resection: a comparative study. Surg Endosc. 2003; 17(12):1914-8. Epub 2003 Oct 28

54. Gagner M, Rogula T, Selzer D. Laparoscopic liver resection: benefits and controversies. Surg Clin North Am. 2004;84(2):451-62.

55. O'Rourke N, Fielding G. Laparoscopic right hepatectomy: surgical technique. J Gastrointest Surg. 2004:8(2):213-6.

56. Belghiti J, Guevara OA, Noun R, Saldinger PF, Kianmanesh R. Liver hanging maneuver: a safe approach to right hepatectomy without liver mobilization. J Am Coll Surg. 2001;193(1):109-11.

57. Marcal LP, Patnana M, Bhosale P, Bedi DG. Intraoperative abdominal ultrasound in oncologic imaging. World J Radiol. 2013;5(3):51-60. doi: 10.4329/wjr.v5.i3.51.

58. Torzilli G, Leoni P, Gendarini A, Calliada F, Olivari N, Makuuchi M. Ultrasound-guided liver resections for hepatocellular carcinoma. Hepatogastroenterology. 2002;49(43):21-7.

59. Lesurtel M, Selzner M, Petrowsky H, McCormack L, Clavien PA. How should transection of the liver be performed?: a prospective randomized study in 100 consecutive patients: comparing four different transection strategies. Ann Surg. 2005;242(6):814-22, discussion 822-3.

60. Bui LL, Smith AJ, Bercovici M, Szalai JP, Hanna SS. Minimising blood loss and transfusion requirements in hepatic resection. HPB (Oxford). 2002;4(1):5-10. doi: 10.1080/136518202753598672.

61. Pulitano C, Arru M, Bellio L, Rossini S, Ferla G, Aldrighetti L. A risk score for predicting perioperative blood transfusion in liver surgery. Br J Surg. 2007:94:860-5.

62. Kooby DA, Stockman J, Ben-Porat L, Gonen M, Jarnagin WR, Dematteo RP, et al. Influence of transfusions on perioperative and long-term outcome in patients following hepatic resection for colorectal metastases. Ann Surg. 2003;237(6):860-9; discussion 869-70.

63. de Boer MT, Molenaar IQ, Porte RJ. Impact of blood loss on outcome after liver resection. Dig Surg. 2007;24(4):259-64. Epub 2007 Jul 27.

64. Asahara T, Katayama K, Itamoto T, Yano M, Hino H, Okamoto Y, et al Perioperative blood transfusion as a prognostic indicator in patients with hepatocellular carcinoma. World J Surg. 1999;23(7):676-80.

65. Smyrniotis V, Farantos C, Kostopanagiotou G, Arkadopoulos N. Vascular control during hepatectomy: review of methods and results. World J Surg. 2005;29(11):1384-96.

66. Makuuchi M, Mori T, Gunven P, Yamazaki S, Hasegawa H. Safety of hemihepatic vascular occlusion during resection of the liver. Surg Gynecol Obstet. 1987;164(2):155-8.

67. Clavien PA, Yadav S, Sindram D, Bentley RC. Protective effects of ischaemic preconditioning for liver resection performed under inflow occlusion in humans. Ann Surg. 2000;232(2):155-62.

68. Huguet C, Addario-Chieco P, Gavelli A, Arrigo E, Harb J, Clement RR. Technique of hepatic vascular exclusion for extensive liver resection. Am J Surg. 1992;163(6):602-5.

69. Eyraud D, Richard O, Borie DC, Schaup B, Carayon A, Vezinet C, et al. Hemodynamic and hormonal responses to the sudden interruption of caval flow: Insights from a prospective study of hepatic vascular exclusion during major liver resections. Anesth Analg. 2002; 95(5): 1173-8, table of contents.

70. Wang WD, Liang LJ, Huang XQ, Yin XY. Low central venous pressure reduces blood loss in hepatectomy. World J Gastroenterol. 2006; 12(6):935-9.

71. Eder F, Meyer F, Nestler G, Halloul Z, Lippert H. Sealing of the hepatic resection area using fibrin glue reduces significant amount of post-operative drain fluid. World J Gastroenterol. 2005;11(38): 5984-7. 
72. Tanaka S, Hirohashi K, Tanaka H, Shuto T, Lee SH, Kubo S, et al. Incidence and management of bile leakage after hepatic resection for malignant hepatic tumors. J Am Coll Surg. 2002;195(4):484-9.

73. Aldameh A, McCall JL, Koea JB. Is routine placement of surgical drains necessary after elective hepatectomy? Result from a single institution. J Gastrointest Surg. 2005;9(5):667-71.

74. Sun HC, Qin LX, Lu L, Wang L, Wang L, Ye QH, et al. Randomised clinical trial of the effects of abdominal drainage after elective hepatectomy using the crushing clamp method. Br J Surg. 2006; 93(4):422-6.

75. Alexandrescu S, Diaconescu A, Anghel R, Croitoru A, Boros M, Ionescu M, et al. Surgical treatment of recurrent colorectal cancer metastases. Chirurgia (Bucur). 2008; 103 Suppl 1:S34-S35.

76. LiverMetSurvey.com. Semestrial statistics 2017. Ref Type: Online Source http://51.255.95.173:81/SASStoredProcess/guest?_debug $=0$ \&_program=/livermetsurvey/Applications $\% 20$ stockees/00\%20L iverMetSurvey.sas.

77. Hasegawa K, Kokudo N, Imamura H, Matsuyama Y, Aoki T, Minagawa $\mathrm{M}$, et al. Prognostic impact of anatomic resection for hepatocellular carcinoma. Ann Surg. 2005;242(2):252-9.

78. Kaibori M, Matsui Y, Hijikawa T, Uchida Y, Kwon AH, Kamiyama Y. Comparison of limited and anatomic hepatic resection for hepatocellular carcinoma with hepatitis C. Surgery. 2006;139(3):385-94.

79. Sarpel U, Bonavia AS, Grucela A, Roayaie S, Schwartz ME, Labow DM. Does anatomic versus nonanatomic resection affect recurrence and survival in patients undergoing surgery for colorectal liver metastasis? Ann Surg Oncol. 2009;16(2):379-84. doi: 10.1245/s10434-008-0218-2. Epub 2008 Nov 20.

80. Zorzi D, Mullen JT, Abdalla EK, Pawlik TM, Andres A, Muratore A, et al. Comparison between hepatic wedge resection and anatomic resection for colorectal liver metastases. J Gastrointest Surg. 2006; 10(1):86-94.

81. Ochiai T, Takayama T, Inoue K, Yamamoto J, Shimada K, Kosuge T, et al. Hepatic resection with and without surgical margins for hepatocellular carcinoma in patients with impaired liver function. Hepatogastroenterology. 1999;46(27): 1885-9.

82. Shi M, Guo RP, Lin XJ, Zhang YQ, Chen MS, Zhang CQ, et al. Partial hepatectomy with wide versus narrow resection margin for solitary hepatocellular carcinoma: a prospective randomized trial. Ann Surg. 2007;245(1):36-43.

83. Matsui Y, Terakawa N, Satoi S, Kaibori M, Kitade H, Takai S, et al. Postoperative outcomes in patients with hepatocellular carcinomas resected with exposure of the tumor surface: clinical role of the no-margin resection. Arch Surg. 2007;142(7):596-602; discussion 603.

84. Pawlik TM, Scoggins CR, Zorzi D, Abdalla EK, Andres A, Eng C, et al. Effect of surgical margin status on survival and site of recurrence after hepatic resection for colorectal metastases. Ann Surg. 2005;241(5):715-22, discussion 722-4.

85. Figueras J, Burdio F, Ramos E, Torras J, Llado L, Lopez-Ben S, et al. Effect of subcentimeter nonpositive resection margin on hepatic recurrence in patients undergoing hepatectomy for colorectal liver metastases. Evidences from 663 liver resections. Ann Oncol. 2007; 18(7):1190-5.

86. Torzilli G, Adam R, Viganò L, Imai K, Goransky J, Fontana A, et al. Surgery of colorectal liver metastases: Pushing the Limits. Liver Cancer. 2016;6(1):80-89.
87. Viganò L, Procopio F, Cimino MM, Donadon M, Gatti A, Costa G, et al. Is tumor detachment from vascular structures equivalent to $\mathrm{r} 0$ resection in surgery for colorectal liver metastases? An observational cohort. Ann Surg Oncol. 2016;23(4):1352-60. doi: 10.1245/s10434 -015-5009-y. Epub 2015 Dec 29.

88. de Haas RJ, Wicherts DA, Flores E, Azoulay D, Castaing D, Adam R. R1 resection by necessity for colorectal liver metastases: is it still a contraindication to surgery? Ann Surg. 2008; 248(4):626-37.

89. Popescu I, Alexandrescu S, Croitoru A, Boros M. Strategies to convert to resectability the initially unresectable colorectal liver metastases. Hepatogastroenterology. 2009;56(91-92):739-44.

90. Popescu I, Alexandrescu ST. Surgical options for initially unresectable colorectal liver metastases. HPB Surg. 2012;2012: 454026. doi: 10.1155/2012/454026. Epub 2012 Oct 3.

91. Azoulay D, Castaing D, Smail A, Adam R, Cailliez V, Laurent A, et al. Resection of nonresectable liver metastases from colorectal cancer after percutaneous portal vein embolization. Ann Surg. 2000; 231(4):480-6.

92. Di Stefano DR, de Baere T, Denys A, Hakime A, Gorin G, Gillet M, et al. Preoperative percutaneous portal vein embolization: evaluation of adverse events in 188 patients. Radiology. 2005;234(2):625-30. Epub 2004 Dec 10.

93. Adam R, Laurent A, Azoulay D, Castaing D, Bismuth H. Two-stage hepatectomy: A planned strategy to treat irresectable liver tumors. Ann Surg. 2000;232(6):777-85.

94. Jaeck D, Oussoultzoglou E, Rosso E, Greget M, Weber JC, Bachellier P. A two-stage hepatectomy procedure combined with portal vein embolization to achieve curative resection for initially unresectable multiple and bilobar colorectal liver metastases. Ann Surg. 2004; 240(6):1037-49; discussion 1049-51.

95. Schnitzbauer AA, Lang SA, Goessmann H, Nadalin S, Baumgart J, Farkas SA, et al. Right portal vein ligation combined with in situ splitting induces rapid left lateral liver lobe hypertrophy enabling 2staged extended right hepatic resection in small-for-size settings. Ann Surg. 2012;255(3):405-14. doi: 10.1097/SLA.0b013e31824856f5.

96. Torzilli G, Procopio F, Botea F, Marconi M, Del Fabbro D, Donadon $M$, et al. One-stage ultrasonographically guided hepatectomy for multiple bilobar colorectal metastases: a feasible and effective alternative to the 2-stage approach. Surgery. 2009;146(1):60-71. doi: 10.1016/j.surg.2009.02.017.

97. Torzilli G, Palmisano A, Procopio F, Cimino M, Botea F, Donadon M, et al. A new systematic small for size resection for liver tumors invading the middle hepatic vein at its caval confluence: minimesohepatectomy. Ann Surg. 2010;251(1):33-9.

98. Tsao JI, Loftus JP, Nagorney DM, Adson Ma, Ilstrup DM. Trends in morbidity and mortality of hepatic resection for malignancy: a matched comparative analysis. Ann Surg. 1994;220(2):199-205.

99. Dimick JB, Pronovost PJ, Cowan JA, Lipsett PA. Postoperative complication rates after hepatic resection in Maryland hospitals. Arch Surg. 2003;138(1):41-6.

100. Choti MA, Bowman HM, Pitt HA, Sosa JA, Sitzmann JV, Cameron $\mathrm{JL}$, et al. Should hepatic resections be performed at high-volume referral centers? J Gastrointest Surg. 1998;2(1):11-20.

101. Glasgow RE, Showstack JA, Katz PP, Corvera CU, Warren RS, Mulvihill SJ. The relationship between hospital volume and outcomes of hepatic resection for hepatocellular carcinoma. Arch Surg. 1999;134(1):30-5. 